\title{
Evaluation of Gastrointestinal System Findings in Crimean-Congo Hemorrhagic Fever Patients
}

\author{
Ayşe İnci' ${ }^{1}$ Utku Murat Kalafat' ${ }^{2}$, Mustafa Baştürk², Serkan Doğan², Tarık Ocak² \\ 'Department of Infectious Diseases and Clinical Microbiology, Kanuni Sultan Süleyman Education and Research Hospital, İstanbul, Turkey \\ 2Department of Emergency Medicine, Kanuni Sultan Süleyman Education and Research Hospital, İstanbul, Turkey
}

\begin{abstract}
Aim: Crimean-Congo hemorrhagic fever (CCHF) is a disease caused by a virus. Early diagnosis of CCHF particularly in regions where the disease frequently occurs is important for taking necessary measures and for immediately starting the treatment process. This study aims to evaluate gastrointestinal system (GIS) findings in the patients.

Materials and Methods: Patient history, such as nausea, vomiting, abdominal pain, diarrhea, values of aspartate aminotransferase (AST) and alanine aminotransferase (ALT) levels, and contact with tick, was recorded. Enzyme-linked immunosorbent assay and/or Polymerase Chain Reaction tests were used for diagnoses.

Results: The ratio of tick bite history was found to be $73.1 \%$. According to the GIS findings of the patients at the time of admission, the ratio of nausea and vomiting, abdominal pain, diarrhea, and elevated AST and ALT levels were $61.2 \%, 37.6 \%, 27.9 \%$, and $78.4 \%$ respectively. Five of the 93 patients died, and the mortality rate was $5.4 \%$.

Conclusion: Considering that early diagnosis is vital for the clinical course of the patients and the prevention of hospital infections and that every patient may not have a history of tick bite, it should be kept in mind that the disease can occur particularly with GIS findings in high season living in endemic regions and thus CCHF should be suspected. (Eurasian J Emerg Med 2016; 15: 105-7)
\end{abstract}

Keywords: Crimean-Congo Hemorrhagic Fever, gastrointestinal findings, tick, viral hemorrhagic fever

\section{Introduction}

Crimean-Congo hemorrhagic fever (CCHF) is a disease caused by a virus of the Bunyaviridea family and has been reported in Asia, Africa, the Middle East, and Eastern European regions, as well as has been observed in Turkey since 2002. Early diagnosis of the disease, particularly in regions where it frequently occurs, is important for taking isolation measures and for immediately starting the treatment process (1).

The infection can be transmitted by contact with a CCHF-infected person, infected ticks, and farm animals. It clinically presents with a dramatic progress characterized by diffused hemorrhages, weakness, and fever. Liver enzymes, creatinine phosphokinase, and lactate dehydrogenase levels of these patients are elevated, and an endothelium infection plays a profound pathogenic role (2).

Crimean-Congo hemorrhagic fever, which is transmitted by ticks, is noteworthy because of its increasing prevalence and resulting mortality, particularly in recent years. Early diagnosis is important for a better clinical course of the patient and for the prevention of hospital infections. Management of patients is based on supportive care $(3,4)$.
Laboratory diagnosis of CCHF is made by identifying viral nucleic acids using a real-time reverse transcriptase polymerase chain reaction (PCR) or by identifying lgM positive or lgG seroconversion using enzyme-linked immunosorbent assay (ELISA) in blood or body fluid samples (5).

The symptoms occur because of the direct effect of the virus on target organs. Immunohistochemical analyses have shown the presence of intense antigens in the endothelium and liver. Symptoms in the early period of the disease are non-specific and can be confused with various manifestations. Nausea, vomiting, abdominal pain, and short-term diarrhea can occur in the early stage of the disease. Hypovolemia, hypoxia, and shock can develop in patients who have simultaneous hemorrhage from various regions, particularly in the gastrointestinal system (GIS) (6). In this study, we aimed to evaluate GIS findings in CCHF patients at the time of admission to the hospital.

\section{Materials and Methods}

We retrospectively evaluated 93 patients in Artvin who were diagnosed with CCHF in the period from January 2011 to April 2014, using

Correspondence to: Utku Murat Kalafat e-mail: utkumuratk@yahoo.com 
computer records of the patients. Patients' history of nausea, vomiting, abdominal pain, diarrhea, aspartate aminotransferase (AST), alanine aminotransferase (ALT) elevation levels, and contact with ticks were recorded from the national case report form of CCHF. Because the patients' data were obtained from the National CCHF form, numerical data could not be obtained; GIS findings of the patients in this system are not reported in numerical values but instead are recorded as "yes/no."

ELISA and/or PCR tests were performed to diagnose the patients from blood samples analyzed by a reference laboratory. ELISA was used to determine CCHF virus Immunoglobulin IgM antibody positivity and Real-Time PCR was used to determine the presence of CCHF viral RNA. Data were analyzed using the Statistical Package for the Social Sciences (SPSS Inc., Chicago, IL, USA) version 15. Results were reported as a numerical value, percentage, and mean.

\section{Results}

The study included a total of 93 patients with CCHF in the emergency service of Artvin Government Hospital. The demographic characteristics of the patients were as follows: 50 were men and 43 were women; mean age was $44.8 \pm 10.8$ years. The proportion of patients with tick bite history was $73.1 \%$. According to the GIS findings of the patients at the time of admission, $61.2 \%$ had nausea and vomiting, $37.6 \%$ had abdominal pain, $27.9 \%$ had diarrhea, and $78.4 \%$ had elevated AST and ALT levels. Five of the 93 patients with CCHF died, and the mortality rate was $5.4 \%$ (Table 1 ).

\section{Discussion}

Crimean-Congo hemorrhagic fever disease is characterized by signs and symptoms like fever, nausea, vomiting, headache, myalgia, elevated liver enzymes, and mucocutaneous hemorrhage, as well as life-threatening intravenous coagulation and massive hemorrhages
(7). GIS findings of CCHF patients from some previous studies are presented for comparison in Table $2(8-19,21,22)$.

Crimean-Congo hemorrhagic fever is more common in people of the working age dealing with agriculture and animal husbandry who are more exposed to tick bites than other members of the population (4). In our study, $75 \%$ of the patients were found to have a history of tick bites. This proportion ranged between $50 \%$ and $82 \%$ in previous studies $(8,9,11-16,18,19)$.

In our study, levels of nausea and vomiting rose to $80 \%$ and elevated AST and ALT to $100 \%$ in patients who died from CCHF. We detected a significantly higher proportion of nausea and vomiting in the deceased patients than in the survivors. Bakir et al. (13) reported significantly higher AST levels in deceased patients in their study. Ergonul et al. (14) observed that the proportions of melena, hematemesis, and nausea and vomiting were $100 \%$ in deceased patients. Hatipoglu et

Table 1. Evaluation of GIS findings of the patients with CCHF

\begin{tabular}{|l|c|c|c|}
\hline & $\begin{array}{c}\text { Survivors } \\
(\mathbf{n = 8 8})\end{array}$ & $\begin{array}{c}\text { Death } \\
(\mathbf{n = 5 )}\end{array}$ & $\begin{array}{c}\text { Total } \\
(\mathbf{n = 9 3 )} \\
\mathbf{n}(\%)\end{array}$ \\
\hline Age mean \pm SD & $41.1 \pm 15.7$ & $38.9 \pm 15.1$ & $40.8 \pm 10.8$ \\
\hline Male/Female & $47 / 41$ & $3 / 2$ & $50 / 43$ \\
\hline Tick bite history & 63 & 5 & $68(73.1)$ \\
\hline Nausea and vomiting & 53 & 4 & $57(61.2)$ \\
\hline Abdominal pain & 33 & 2 & $35(37.6)$ \\
\hline Diarrhea & 25 & 1 & $26(27.9)$ \\
\hline Elevated AST, ALT & 68 & 5 & $73(78.4)$ \\
\hline
\end{tabular}

GIS: Gastrointestinal System; CCHF: Crimean-Congo Hemorrhagic Fever; AST: Aspartate aminotransferase; ALT: Alanine aminotransferase

Table 2. The percentages of GIS findings of CCHF patients from previous studies

\begin{tabular}{|c|c|c|c|c|c|c|c|c|c|}
\hline Study & Nausea & Vomiting & Diarrhea & $\begin{array}{l}\text { Abdominal } \\
\text { Pain }\end{array}$ & $\begin{array}{l}\text { Elevated } \\
\text { AST/ALT }\end{array}$ & Hematemesis & Melena & HM & $\begin{array}{l}\text { Number } \\
\text { of Cases }\end{array}$ \\
\hline Gonen (8) & 40 & 40 & 20 & 40 & 60 & 6 & & & 15 \\
\hline Ozturk et al. (9) & 70 & 45 & 35 & 25 & & & & 5 & 20 \\
\hline Karti et al. (10) & 84 & 84 & 37 & 84 & & & & 21 & 19 \\
\hline Ertugrul et al. (11) & 69 & 46 & 35 & 42 & 77 & & & & 25 \\
\hline Cevik et al. (12) & 51 & 51 & 20 & & & 13 & 17 & 19 & 69 \\
\hline Bakir et al. (13) & 75 & 68 & 33 & & & 8 & 1 & 30 & 92 \\
\hline Ergonul et al. (14) & 83 & 83 & 35 & & & 31 & 20 & 35 & 54 \\
\hline Ergonul et al. (16) & 80 & 80 & 31 & & & 29 & 17 & 37 & 35 \\
\hline Belet et al. (17) & 39 & 59 & 22 & 22 & $61 / 29$ & & & & 54 \\
\hline Tuygun et al. (18) & 60 & 60 & & & & & & & 50 \\
\hline Yilmaz et al. (19) & 65 & 43 & 25 & 33 & 86 & & & & 1820 \\
\hline Schwarz et al. (21) & 64 & & 46 & & & & & & 11 \\
\hline Kadanali et al. (22) & 60 & 48 & 19 & & & & & 20 & 63 \\
\hline Present study & 61.2 & 61.2 & 27.9 & 37.6 & 78.4 & & & & 93 \\
\hline
\end{tabular}


al. (20) reported that the proportion of diarrhea and ALT and AST values of the deceased patients were higher than of those who survived. Kadanali et al. (22) similarly found a vomiting proportion of $100 \%$ and found that AST and ALT levels were higher in the deceased patients than in those who survived.

A literature review from Turkey revealed a CCHF patient who was admitted to the hospital with a clinical presentation mimicking acute appendicitis, another patient who was admitted with abdominal pain and hematemesis, and another one who was admitted because of elevated transaminase $(23,24)$. Similarly, the literature contains a case presentation involving a patient who was admitted to hospital because of abdominal pain and died within $24 \mathrm{~h}$ (25). In a study carried out in India, it was reported that two patients were admitted to the hospital for abdominal pain and vomiting (26). The proportion of abdominal pain was $37.6 \%$ in the patients of the present study.

In a study performed in Turkey that included 42 dyspeptic patients hospitalized because of CCHF, the patients were divided into two groups according to fecal Helicobacter pylori positivity and the clinical and laboratory acuteness criteria of CCHF; the study reported no difference between the two groups in terms of clinical and laboratory criteria (27).

\section{Conclusion}

In our study, we observed the GIS findings of CCHF patients as $61.2 \%$ of the patients had nausea and vomiting, $37.6 \%$ had abdominal pain and $27.9 \%$ had diarrhea. Because not all patients had a history of tick bite, it should kept in mind that the disease can occur with GIS findings in the high season, particularly in people living in endemic regions; therefore, CCHF should be suspected.

Ethics Committee Approval: Ethics committee approval is not required because of our study was performed retrospectively.

Informed Consent: Written informed consent is not required because of our study was performed retrospectively.

Peer-review: Externally peer-reviewed.

Conflict of Interest: No conflict of interest was declared by the authors.

Financial Disclosure: The authors declared that this study has received no financial support.

\section{References}

1. Yilmaz GR, Buzgan T, Cevik MA, Safran A, Uzun R, Cevik MA, et al. The Evaluation of Knowledge of the Health-Care Personnel Regarding Crimean-Congo Haemorrhagic Fever. Flora J 2009; 4: 27-35.

2. Ergonul O. Crimean-Congo haemorrhagic fever. Lancet Infect Dis 2006; 6: 203-14. [CrossRef]

3. Kaygusuz S. Preliminary Study Indicating the Epidemiological Situation of the Ticks in Kırıkkale-Kızılırmak Basın. Kırıkkale Uni J 2008; 10: 1-4.

4. Ergonul O. Crimean-Congo Haemorrhagic Fever. Ankem J 2009; 23: 23440.

5. Uyar Y, Carhan A, Albayrak N, Altas AB. Evalution of PCR and ELISA-IgM results in the laboratory diagnosis of Crimean-Congo haemorrhagic fever cases in 2008 in Turkey. Microbiology J 2010; 44: 57-64.

6. Ozkurt Z. Crimean-Congo haemorrhagic fever. Intensive Care J 2007; 7: 85-90.

7. Duru F, Fisgin T. Hematological aspects of Crimean-Congo hemorrhagic fever. Turk J Hematol 2009; 26: 161-6.
8. Gonen I. Clinical and laboratory findings of patients with Crimean-Congo hemorrhagic fever in the emergency department at hospital admission. JMID 2011; 1: 1-4. [CrossRef]

9. Ozturk DB, Kuscu F, Gurbuz Y, Gül S, Tütüncü EE, Şencan I. Evaulation of 20 CCHF cases during 2006-2007 years. Klimik J 2008; 21: 93-6.

10. Karti SS, Odabasi Z, Korten V, Yilmaz M, Sonmez M, Caylan R, et al. Crimean-Congo hemorrhagic fever in Turkey. Emerg Infect Dis 2004; 10: 137984. [CrossRef]

11. Ertugrul B, Uyar Y, Yavas K, et al: An outbreak of Crimean-Congo hemorrhagic fever in western Anatolia, Turkey International Journal of Infectious Diseases 2009;13:431-436.

12. Ertugrul B, Uyar Y, Yavas K, Turan C, Oncu S, Saylak O, et al. Clinical and laboratory features of Crimean-Congo hemorrhagic fever: predictors of fatality. Int J Infect Dis 2008; 12: 374-9. [CrossRef]

13. Bakir M, Ugurlu M, Dokuzoguz B, Bodur $\mathrm{H}$, Tasyaran MA, Vahaboglu $\mathrm{H}_{\text {, }}$ et al. Crimean-Congo haemorrhagic fever outbreak in Middle Anatolia: a multicentre study of clinical features and outcome measures. J Med Microbiol 2005; 54: 385-9. [CrossRef]

14. Ergonul O, Celikbas A, Baykam N, Eren S, Dokuzoguz B. Analysis of risk-factors among patients with Crimean-Congo haemorrhagic fever virus infection: severity criteria revisited. Clin Microbiol Infect 2006; 12 551-4. [CrossRef]

15. Midilli K, Gargili A, Ergonul O, Sengöz G, Ozturk R, Bakar M, et al. Imported Crimean-Congo hemorrhagic fever cases in Istanbul. BMC Infect Dis 2007; 7: 54. [CrossRef]

16. Ergönül O, Celikbaş A, Dokuzoguz B, Eren S, Baykam N, Esener H. Characteristics of patients with Crimean-Congo hemorrhagic fever in a recent outbreak in Turkey and impact of oral ribavirin therapy. Clin Infect Dis 2004; 39: 284-7. [CrossRef]

17. Belet N, Top A, Terzi O, Arslan HN, Baysal K, Sensoy G. Evaluation of children with Crimean-Congo hemorrhagic fever in the central Blacksea region. Pediatr Infect Dis J 2014; 33: e194-7.

18. Tuygun N, Tanir G, Caglayik DY, Uyar Y, Korukluoglu G, Cenesiz F. Pediatric cases of Crimean-Congo hemorrhagic fever in Turkey. Pediatr Int 2012; 54: 402-6. [CrossRef]

19. Yilmaz GR, Buzgan T, Irmak H, Safran A, Uzun R, Cevik MA, et al. The epidemiology of Crimean-Congo hemorrhagic fever in Turkey, 2002-2007. Int J Infect Dis 2009; 13: 380-6. [CrossRef]

20. Hatipoglu CA, Bulut C, Yetkin MA, Ertem GT, Erdinc FS, Kilic EK, et al. Evaluation of clinical and laboratory predictors of fatality in patients with Crimean-Congo haemorrhagic fever in a tertiary care hospital in Turkey. Scand J Infect Dis 2010; 42: 516-21. [CrossRef]

21. Schwarz TF, Nsanze H, Ameen AM. Clinical features of Crimean-Congo haemorrhagic fever in the United Arab Emirates. Infection 1997; 25: 364 7. [CrossRef]

22. Kadanali A, Ozden K, Erol S. Crimean-Congo Hemorrhagic Fever Virus Infection: Clinical and Laboratory Observations and Predictors of Fatality. Turkiye Klinikleri J Med Sci 2012; 32: 432-7. [CrossRef]

23. Celikbas A, Ergonul O, Dokuzoguz B, Eren S, Baykam N, Polat-Düzgün A. Crimean-Congo hemorrhagic infeciton simulating ace apendicitis. J Infect 2005; 50: 363-5. [CrossRef]

24. Gonen I, Ermis F. Crimean-Congo hemorrhagic fever presenting with gastrointestinal manifestations: two cases. Turk J Gastroenterol 2014; 25: 120-1. [CrossRef]

25. Saleem J, Usman M, Nadeem A, Sethi SA, Salman M. Crimean-Congo hemorrhagic fever: a first case from Abbottabad, Pakistan. Int J Infect Dis 2009; 13: e121-3.

26. Patel AK, Patel KK, Mehta M, Parikh TM, Toshniwal H, Patel K. First Crimean-Congo hemorrhagic fever outbreak in India. J Assoc Physicians India 2011; 59: 585-9.

27. Dokmetas I, Yonem O, Dokmetas S, Ozdemir L, Kilicli F, Engin A, et al. Effect of $\mathrm{H}$. pyloripresence on the severity of Crimean Congo hemorrhagic fever. Endoscopy J 2014; 22: 11-3. 